\title{
A Review of the Theory of Wealth and Poverty
}

\author{
Shun Yi \\ Zhaoqing University \\ Zhaoqing, China 526000
}

\author{
AmyMya Menghua Liu \\ South China Business College \\ Guangdong University of Foreign Studies \\ Guangzhou, China 510545
}

\begin{abstract}
This paper summarizes the explanations of the ancient problems of the rich countries in western economics, and uses the historical comparative analysis method to clarify a vein. From Adam Smith's theory of exchange of division of labor and specialization of the neoclassical growth theory, and then from Marx's theory of institutional change to North's theory of institutional change, these theories have failed to explain the nature of economic development is the most real. The only way to do this is by looking at the typical case of Genoa and Maghreb. And aiming at the shortcomings of the north ideology theory, Greif believed that ideology is the culture, the game analysis, introduced in the process of analysis, thus effectively made up for the inadequacy of our predecessors, only history comparative institutional analysis explains the problems of rich countries to poor.
\end{abstract}

Keywords-culture; economic development; institutional change; historical comparison institutional analysis

\section{INTRODUCTION}

Why is there a big difference in the level of economic development? What is the root cause of the country's economic success? These questions have attracted the attention of many scholars. Since Adam Smith published the Wealth of Nations, to explore the cause of rich countries and the poor, to the Max. Weber's "the Protestant Ethic and the Spirit of Capitalism", insisting on the European progress due to the rise of protestant ethic socialism to Douglas. North in the Rise of the Western World, explicit the institution and the relationship between economic growth. In the two hundred years, how to make a country rich and strong is the problem that most economists made efforts. However, the political, economic and social reasons for the poor countries in the rich countries still vary widely in academic circles. The theory of the reasons for the poor countries in rich countries is expounded, and there are some defects. As reviewed in this paper, the classic views on the rich countries to poor is inadequate for the problem since hundreds of years of history has provided a comprehensive picture of theory. On this basis, we hope from the academic's view on the rich countries to poor countries, we will detect the most fundamental reason of economic development.

\section{THE "SMITH POWER" WAS ThWARTED BY THE "BRAUDEL BELL JAR"}

According to Adam Smith, the originator of economics, the power of human social and economic development depends on the improvement of labor productivity brought by division of labor and specialization. In other words, the economic development of human society is the same as the deepening and expansion of the market. From the internal mechanism of market expansion, market transaction is the original motivation and path of any civilized social economic growth, people's income increase and living standard. Market transactions come from the division of labor, which in turn promotes the division of labor, which is limited by the size of the market. The acceleration and deepening of the division of labor in the market, thus deepening and expanding the economic growth and market, actually constitute two sides of the same coin. This division of labor and the mutual promotion of market expansion constitute the "Smith power" of any social and economic growth. If, according to Adam Smith, there is a specialization and specialization within a country, it can increase the productivity of a country and thus lead to economic development. However, we can see, in the world of Europe, yat sen villa in period of the Chinese empire is another story, although China's market economy has a certain development, especially in the jiangnan region, once presents a scene of prosperity, but then gradually declined, and even here Adam. Smith found the internal mechanism of economic development, but the lack of didn't explain why not all countries can establish such a mechanism. In view of Adam Smith's theoretical flaw, the Peruvian economist, disotto, has a very meaningful concept in his famous book the riddle of capital, which is the "Braudel bell jar". According to Hayek, market economy is a kind of human cooperative order which is constantly growing and expanding spontaneously. In the history of mankind, the cooperation and expand order is often unknown constrained by social factors and social mechanism, causes the extended order cannot be self-expansion and the society as a whole, thus in the history of the market economy seemed to be trapped in an isolated within the "bell".

Why China began to lag behind the world in mid and late qing dynasty, largely because of the qing dynasty of China and on the evolution of institutions without any fundamental change, while the market economy in China has certain development, but due to some promote deepening of division of labor and market expansion property of an effective legal institution and support property legal institution of constitutional democracy have not been able to form, inside the Chinese empire of the qing period, higher market extension, deepening division of labor and specialization degree hasn't been much improvement, from the aspects such as the first three factors interaction a joint result of the development of science and technology revolution, also has 
not occurred in modern Chinese society. Chinese traditional cultural spirit can be expressed as "realistic spirit" coordination, its basic characteristic is based on the secular human relations as the core, through the coordination of the ethical awareness to realize the cultural and social selfaffirmation. Under the control of the Chinese people in such a spirit, the institution of the old Chinese society will not be a fundamental change, the economic development of the institution of "dynamic" Smith was missing this Fernand Braudel bell firmly by the restrictions. Another classic case is India. From the form in the contemporary Indian society has a clear property right structure, perfecting the legal institution as well as the representative of a democratic constitution of a well-ordered market operation of the three basic conditions, but why India cannot in a huge population and human resources and huge market failed to achieve the economic take-off in the space? In India, ethnic composition, language, religion and social class are very complex (more than 300 national, 180 languages, dozens of religion and caste institution), especially the caste institution, the economy is divided into different social groups, form the incompatible small interest groups, their own, so it is difficult to form a unified and orderly national market. Personal careers are fixed and passed on from generation to generation. The whole social class solidified, which severely limits and restricts their creativity and enthusiasm.

\section{DEFECTS OF NEOCLASSICAL GROWTH THEORY}

Orthodox neo-classical economics production function is used to explain the economic growth, that is, output is labor, capital, land, entrepreneurship and technology function of increasing output depends on the factors of production inputs increase, and the improvement of production technology. Neoclassical growth theory can explain the factor contribution to economic growth, however, new classical doesn't address two fundamental questions: first, is also the labor, capital, land, entrepreneurship and technology, why some countries with these factors of production and the other countries is the lack of the neoclassical growth theory does not explain why people save, collect useful knowledge as well as a specific social investment, such as in the 19th century European social born why countless entrepreneurs and other social (e.g., the Chinese society of late qing dynasty) but no; Second, even if the factors of production are equal, why do some countries flourish while others decline? The reason why neoclassical is so weak in explaining such problems is that the assumption institution is irrelevant. Although the new classical theory on what is essential to the long-term growth performance, this point provides a useful quantitative analysis, it doesn't really explain why some social than other more physical capital and human capital accumulation. Growth of neoclassical growth theory, therefore, provides approximate explanation, said they are still not clear, why do people saving, investment and development of natural resources, learning skills, or why they don't do this.

Similarly, neoclassical economics does not answer the question of why, in non-European cultures, great advances in technical knowledge have not led to an industrial revolution.
In particular, why has China's superior technology, especially in the song dynasty, never turned into an industrial revolution? This has long been a mystery in economic history. In fact, the root cause of this problem is on the culture, in China and other Asian powers, due to the particular culture makes these countries lack certain social, political and legal premise, the lack of a certain institution. In those huge closed economy, the unification of the country (such as China, since the qin shi huang unified state formation), rulers within its territory without (like medieval Europe after) to attract and retain people with knowledge, have entrepreneurial talents and competition, and the rulers also does not need to cultivate those who gather capital and attractive to the enterprise institution. In other words, in Asia, cultural reasons lead to institutional development not enough to make the accumulation of technological progress and potentially huge markets work.

\section{The DEVElopment of Institutional Change THEORY: FROM MARX TO NORTH}

According to Marx, the mechanization of the revolution gave birth to the capitalist institution, and the capitalist economy has been developed unprecedentedly. However, due to the workers' movement, successively set up several socialist countries in the world, according to Marx, the socialist institution is more superior than the institution of capitalism institution, so the socialist productivity should be far more than capitalism, but we can see the real world is for Marx's theory is a powerful retort. The key of this is that Marx's theory does not solve the dynamic problem of economic development, and the problem of "free rider" is always difficult to solve effectively.

Aiming at Marx's theoretical defects, North proposed a more perfect theory of institutional change. In terms of the power of institutional change, North theory the reverse of thoughts of Marx's historical materialism, Marx's thought of productivity, the development of science and technology) caused by the productivity potential (production) and the contradiction between production relations (property right) change is the motivation and source of social evolution forward; While North thinks that western to fully define the private property rights and the development of efficient economic organizations as the main characteristics of the institution arrangement of social process, is the western modern revolution of science and technology and production technology by a rapid main reason.

Although North in institutional change theory founded its own set of institution, but is still can't deny that some important problems are not solved, one of the most fundamental problem is: why in choosing institution has not been good in many developing countries, such as barbarian invasion of civilization, as a result of decline, relative to the institution structure of China after the wei and jin dynasty han dynasty, the German national socialist alternative in the institution of the market, and the Soviet union's collective farm and China's people's communes brought about by the decline in efficiency of agricultural production and so on. These phenomena raise the theoretical challenge: will the rational economic man and his society choose the institution 
that is unfavorable to him? North argues that people's choice of inefficient institutions is due to occasional "path dependence" (North, 1990), which is clearly unconvincing. Although noth also realized the important role of cultural tradition and ideology, he failed to find a suitable theoretical framework and analytical tool. In fact, the theory of institutional change in North lacks the ultimate explanatory power for the poverty of rich countries.

\section{NEW DEVELOPMENT OF NEW INSTITUTIONAL ECONOMIC HISTORIOGRAPHY: HISTORICAL COMPARISON INSTITUTIONAL ANALYSIS}

In response to the theoretical flaws, Greif argues that the first and most important way to establish a new theory and method is to redefine the broader definition of the institution. Therefore, the institutional analysis of history is defined as the restriction of self-actualized non-technical decision on behavior. It is of great significance to define the institution as the self-enforcing restriction of non-technical decision. Because of the institutional analysis of history, the institution is defined as the self-actualization institution of nontechnical decision, which provides convenience for the institution analysis of game theory widely applied in history.

Greif is aimed at 11-14 th-century Europe "commercial revolution" period of the Italian city of Genoa and is located in North Africa, Mediterranean Maghreb this typical case, a history of comparative institutional analysis. The two regions in the era of the late middle ages have undergone a economic prosperity, but in the subsequent development is on a completely different way: by Genoa Italy to realize the longterm growth of trade and economy, will become the cradle of western world; Even the Muslim world, which was clearly developed in Europe by the Maghreb in the early middle ages, has been in the long-term decline of the economy. Greif is mainly from the Angle of the culture to explain the institution evolution of the two regions, the study found that Genoa directly originated in the ancient Greek and Roman civilization culture spirit of the countries of continental Europe culture and Christianity - can be summed up in a culture of individualism and the Maghreb basically by the Muslim culture spirit osmosis is a kind of community culture. Due to the differences in cultural character, in the late middle ages, there were a lot of institutional arrangements concerning the long-term growth of the future economy, and the Genoa and the Maghreb people made different institutional arrangements. The influence of cultural tradition on the development of state and legal institution is farreaching. In brief, in a Genoa this individualistic society, due to a lack of economic to implement collective punishment mechanism and pass unobstructed information networks, informal economy force level is relatively low, in order to promote exchange, support collective behavior and reduce the free-rider problem, on the basis of the national authority of the legal institution is necessary. Different cultural traditions have profoundly affected the economic and political institution selection and vicissitude of Genoa and Mmaghreb. So eventually in the process of economic and trade development, Genoa, established a set of relatively complete legal institution to regulate the behavior of the economy, people are accustomed to through the courts to settle disputes and the dispute, but very little Maghreb government and legal can provide effective constraint on economic behaviour, businessmen are accustomed to informally signed contracts and settlement of disputes. These different institutional choice and institutional arrangement shows that in the commercial revolution in the late middle ages, Genoa, gradually establish a set of adequate to support the long-term growth market institution, the corresponding legal institution and safeguard institution, and the Maghreb is not set up a similar institution arrangement. That is why the two economies have embarked on different paths of development.

From the above analysis and describe it's not hard to see, to the choice of economic and political institutions and cultural beliefs change had a lasting effect, while the latter is the development status and to a large extent determines the historical trajectory of a social and economic development. Aiming at the existing problem of new institutional economic history, north deliberately increased the ideology theory, but the north has not found a suitable theoretical framework and analysis tools, Greif is a cultural ideology, actually become important history and culture, combined with our previous discussion, the graves are always emphasizes the culture's effects on economic growth, the role of culture in economic development is the fundamental, only history comparative institutional analysis really explain the problems of rich countries to poor.

\section{CONCLUSION}

"The six nations's end, due to the six nations, instead of the Non-qin." China's modern backwardness and disaster are sad, but the external factors should not be ignored, but the tragedy of the clock is already deeply rooted in Chinese culture. For thousands of years, China has advocated naturalism, formed intuitive thinking, lacked sophisticated logical thinking ability, and doomed the lack of natural science to develop the soil, and it was difficult to produce modern science and technology. It is difficult to form a contractual relationship based on trust, and it is difficult to form a contract based economic organization and market economy. Advocating naturalism and lack of theoretical thinking, it is difficult to form stable institution and power balance order. The institution is not the embodiment and extension of political and economic power, but the cultural identity of the whole society. It is the philosophy and belief of all people, which transcends all political and economic interests. Social development without cultural roots is not sound. The institution and the power order have no social cultural identity, and are strong and fragile. Depending on the external environment, without the cultural foundation, the economic development without mastering the core productive forces is not sustainable. The rise of a nation depends not only on the temporary economic indicators, but on the reasonable order and fair rules of society. The changing of the institution is based on the inherent cultural identity of all people, and the cultural state, education, is the right path. 


\section{ACKNOWLEDGEMENT}

This paper was sponsored Doctoral program of Zhaoqing University.

\section{REFERENCES}

[1] Beaud, Michel, A History of Capitalism 1500-1980, trans1by Tom Dickman and Anny Lefebvre, New York: Monthly Review Press, 19831

[2] Braudel, Fernand, Civilization and Capitalism, 15 th-18th Century, Vol12: The Wheels of Comm erce, trans1from the French by Sian Reynolds, London: Collins.

[3] D.Noth, R.Thomas.The Rise of The Western World,Li yiping, Cai leiyi, Beijing: Huaxia Publishing House, 1999.

[4] D.Noth.Structure and Change in Economic History, Translated by Chen yu and Luo hua, Shanghai sanlian bookstore, Shanghai People's Publishing House, 1994.

[5] D. North, 1994. "The Evolution of Efficient Markets In History," Economic History 9411005, EconWPA.

[6] Greif Avner.Historical and Comparative Institutional Analysis[J].American Economic Review, 1998, (2):80-104.

[7] Greif Avner.Institutions:Theory and History.Cambridge: Cambridge University Press.

[8] Greif Avner.Contract Enforceability and Economic Institutions in Early Trade:The Maghribi Traders'Coalition[J] American Economic Review,June 1993, 83(3):525-548.

[9] Greif Avner. Cultural Beliefs and the Organization of Society:A Historical and Theoretical Renection on Collectivistand Individualist societies[J].Joumal of Political Economy,0ctober 1994,102(5):pp.912-950.

[10] Greif Avner. Institutions and the Path to the Modem Economy:Lessons from Medieval Trade[C].Handbook of New Institutional Economics.2005:727-786.

[11] Landes, David.The Wealth and Poverty of Nations: Why Some are so Rich and Some so Poor? New York :W.W.Norton, 1981

[12] K. Marx, F.Engels.The Complete Works of Marx and Engels. Volume 12, People's Publishing House, 1965.

[13] Ke Wu-gang, Shi Man-fei.Institutional Economics-Economic Order and Public Policy, Commercial Press, 2000.

[14] Max Weber.The Protestant Ethic and the Spirit of Capitalism. Translated by Yu xiao, Chen wei-gang et al. 1987.

[15] Max Weber.Confucianism and Taoism" (Religion in China).Translated by Kang le ,Jian meihui, Guangxi Normal University Press, 2004.

[16] Wei sen.The Introduction to Economic Analysis of Social Order.Shanghai Sanlian Bookstore, 2001.

[17] Wei sen.To Reflect the Modern Formation Path of East and West Market Economy from the Cultural Tradition.World Economy. 2002(10): 33-40. 